\title{
Drought Responses of Kentucky Bluegrass and Creeping Bentgrass as Affected by Abscisic Acid and Trinexapac-ethyl
}

\author{
Stephen E. McCann and Bingru Huang ${ }^{1}$ \\ Department of Plant Biology, Cook College, Rutgers University, New Brunswick, NJ 08901
}

\begin{abstract}
AdDitional INDEX wORDs. turfgrass, plant growth regulators, plant growth hormones, water stress tolerance
ABstract. The plant growth regulators abscisic acid (ABA) and trinexapac-ethyl (TE) may affect turfgrass responses to drought stress through regulating shoot growth and water relations. The objectives of this study were to investigate the effects of foliar application of TE and ABA on turf growth of two cool-season turfgrass species, Kentucky bluegrass (Poa pratensis L.) and creeping bentgrass (Agrostis stolonifera L.) exposed to drought stress, and to examine water relations associated with changes in drought tolerance due to TE or ABA treatment. 'L-93' creeping bentgrass and 'Brilliant' Kentucky bluegrass plants were foliar sprayed with $0.904 \mathrm{~mL} \cdot \mathrm{ha}^{-1}$ a.i. TE five times before exposure to drought or with $6.75 \mathrm{~mL} /$ week of $\mathrm{ABA}$ at $100 \mu \mathrm{m}$ before and after exposure to drought in growth chambers. Drought stress was imposed by withholding irrigation until plants were permanently wilted. Foliar application of TE or ABA maintained higher soil volumetric water content, leaf relative water content, and turf quality for a longer period of time during 28 days of stress exposure for Kentucky bluegrass and creeping bentgrass compared with the untreated control. Leaves of TE-treated and ABA-treated plants in both species also had lower $\psi_{\mathrm{S}}$ at 28 days of drought stress than the untreated control. Creeping bentgrass treated with TE or ABA and Kentucky bluegrass treated with TE exhibited significantly lower shoot vertical growth rates at the initiation of drought stress, but maintained higher growth rates during prolonged drought compared with the untreated control. Turf treated with TE or ABA also showed higher levels of photochemical efficiency than the untreated control for both species. Our results suggest that $T E$ or $A B A$ application could prolong the survival of turfgrass under conditions of drought stress by suppressing shoot vertical growth and lowering water use during the early phase of drought and by sustaining growth and photosynthetic activity during prolonged periods of drought stress through osmotic adjustment for retaining cellular hydration.
\end{abstract}

Drought is one of the most detrimental abiotic stresses for turfgrass growth across a wide range of geographic locations. Most cool-season grass species are not well adapted to extended periods of drought, particularly during the summer months. Decline in turf quality caused by drought stress is a major concern in turfgrass culture. Therefore, developing management practices for improving drought resistance of turfgrasses has become imperative in arid and semiarid regions, especially during periods of water use restriction. One strategy to improve plant drought resistance is to promote drought avoidance by reducing water loss during drought, which may be achieved by slowing the growth rate of shoots and lowering the canopy leaf area to reduce the demand for water (Nilsen and Orcutt, 1996). Another mechanism serving to increase drought tolerance is through osmotic adjustment, which allows plants to maintain leaf cellular hydration and sustain metabolic activities during drought (Nilsen and Orcutt, 1996).

Previous studies have reported that plants with slow-growing shoots may survive more extended periods of drought than faster-growing plants (Kondoh et al., 2006; O'Reagan et al., 1993; Simane et al., 1993). Slow growth may reduce the adverse impact of drought by conserving water and carbon energy, such that plants can use limited water to survive drought for an extended period of time (Kang, 2002). Plant

Received for publication 27 Feb. 2007. Accepted for publication 3 Oct. 2007. We thank Syngenta for partial funding of the project. We are also grateful to Dr. Mary Beth Kirkham, Dr. Jack Fry, Dr. Jiang Tian, Dr. Mahalaxmi Veerasamy, Emily Merewitz, Debora Esposito, and Yan Xu for reviewing the manuscript. ${ }^{1}$ Corresponding author. E-mail: huang@aesop.rutgers.edu. growth regulators such as trinexapac-ethyl (TE) are traditionally used to suppress vertical shoot growth for reducing mowing frequency of turfgrasses (Turgeon, 1999). TE blocks the final step in the biosynthesis pathway of the biologically active forms of gibberellins, results in slower vertical shoot growth (King et al., 1997), enhances superoxide dismutase and photochemical activity (Zhang and Schmidt, 2000), and has no negative impact on root growth (Fagerness and Yelverton, 2001). Reduction in vertical shoot growth may reduce the demand for water, and thus, may reduce the water requirement for plant survival in water-limiting conditions for a prolonged period of time. Jiang and Fry (1998) have shown that foliar TE treatments increased turf quality of perennial ryegrass (Lolium perenne L.) during soil dry-down. In our previous work, exogenous application of TE before plant exposure to stress significantly improved growth and physiological activities of creeping bentgrass subjected to combined heat and drought for $21 \mathrm{~d}$ (McCann and Huang, 2007).

Abscisic acid (ABA) is a plant hormone and growth regulator known to be involved in plant adaptation to drought stress. Exogenous application of ABA has been reported to improve drought tolerance in various plant species such as maize (Zea mays L.; Bochicchio et al., 1991), pepper (Capsicum annuum L.; Leskovar and Cantliffe, 1992), old jack pine (Pinus banksiana L.; Rajasekaran and Blake, 1999), and Tradescantia virginiana L. (Franks and Farquhar, 2001). Foliar application of ABA improved the growth of Kentucky bluegrass (Wang et al., 2003) and tall fescue (Festuca arundinacea Schreb.; Huang and Jiang, 2002) under drought stress. ABAinduced plant tolerance to water deficit has been associated with 
changes in various physiological processes, including inhibition of leaf growth or transpirational area for water loss (Alves and Setter, 2000; Bacon et al., 1998), induction of stomatal closure (Kirkham, 1983; Wilkinson and Davies, 2002), and enhancement of osmotic adjustment (Kirkham, 1983; LaRosa et al., 1987).

Although there is evidence that TE or ABA application may promote drought tolerance of turfgrass plants (Huang and Jiang, 2002; Jiang and Fry, 1998; McCann and Huang, 2007; Wang et al., 2003), the information on how TE and ABA may regulate turfgrass responses to drought stress is still limited. In addition, the relative effects of TE and ABA on drought tolerance for different turfgrass species are not well documented. We have hypothesized that treatment of turfgrass plants with TE or ABA may allow plants to survive a prolonged period of drought stress with greater tolerance than controls by regulating shoot growth and water relations. Therefore, the objectives of this study were to investigate the effects of exogenous application of TE and ABA on the responses of two cool-season turfgrass species, Kentucky bluegrass and creeping bentgrass, to drought stress, and to examine changes in water relations associated with improved drought tolerance from TE or ABA treatment.

\section{Materials and Methods}

Plant materials. Sod pieces of 'L-93' creeping bentgrass and 'Brilliant' Kentucky bluegrass were transplanted from field plots into PVC tubes (10-cm diameter and 40-cm length) filled with sterilized sandy loam soil (fine-loamy, mixed mesic Typic Hapludult). Plants were maintained in a greenhouse under natural light conditions with temperatures of $\approx 21{ }^{\circ} \mathrm{C}$ day $/ 13{ }^{\circ} \mathrm{C}$ night for 2 months in Fall 2006 (approximate 12-h photoperiod), and were then moved to a walk-in growth chamber where treatments were imposed. The growth chamber $(3 \times 2.5 \mathrm{~m})$ was set at $20{ }^{\circ} \mathrm{C}$ day $/ 15{ }^{\circ} \mathrm{C}$ night, $12-\mathrm{h}$ photoperiod, with a photosynthetically active radiation level of $450 \mu \mathrm{mol} \cdot \mathrm{m}^{-2} \cdot \mathrm{s}^{-1}$ at the canopy level. Plants in each container were watered three times per week to maintain soil moisture at field capacity and were fertilized weekly with $100 \mathrm{~mL}$ of a soluble fertilizer of 20N-8.8P-16.6K [Peter's General Purpose 20-20-20 with micronutrients $(0.05 \% \mathrm{Mg}, 0.0068 \% \mathrm{~B}, 0.0036 \% \mathrm{Cu}, 0.05 \%$ $\mathrm{Fe}, 0.025 \% \mathrm{Mn}, 0.0009 \% \mathrm{Mo}$, and $0.0025 \% \mathrm{Zn}$ ); Grace-Sierra Horticultural Products Co., Milpitas, CA] at a concentration of $5 \mathrm{~g} \cdot \mathrm{L}^{-1}$ before exposure to drought. Grasses were maintained at a height of $\approx 4 \mathrm{c}$.

Treatments AND EXPerimental Design. The experiment consisted of three treatments: 1) drought stress without TE or ABA treatment (control), 2) drought stress with TE treatment (Stress + TE), and 3) drought stress with ABA treatment (Stress + ABA). For TE treatment, turf was foliar sprayed with a hand-sprayer at $0.904 \mathrm{~mL} \cdot \mathrm{ha}^{-1}$ a.i. TE $\left(0.8 \mathrm{~L} \cdot \mathrm{ha}^{-1}\right.$ Primo Maxx; Syngenta Professional Products, Greensboro, NC) every 2 weeks for 9 weeks before drought stress treatment. This treatment was recommended by the manufacturer for growth inhibition in Agrostis L. and Poa L. species. A total of five TE applications were made, with the final application made 1 week before the initiation of drought stress. For ABA treatment, plants were foliar sprayed with $6.75 \mathrm{~mL}$ of a $100 \mu \mathrm{M} \mathrm{ABA}$, a rate of $54.7 \mathrm{~g} \cdot \mathrm{ha}^{-1}$, weekly, beginning 9 weeks before stress exposure and then weekly during drought treatment. This rate of ABA was previously found to be effective in promoting drought tolerance in Kentucky bluegrass (Wang et al., 2003). A spray mist of water, matching the ABA rate, was also applied to control and TE-treated plants during drought. Treated and untreated plants were exposed to drought stress by withholding irrigation for $28 \mathrm{~d}$. No TE, fertilizers, or irrigation was applied to the plants during the drought stress period. Treatments in each turfgrass species had four replicates (four containers). Treatments and species were arranged as a randomized complete block design in the growth chamber (a total of 24 containers). Statistical significance of data was tested using the analysis of variance procedure (SAS Institute, Cary, NC). Differences between treatment means were separated by Fisher's protected least significance difference (LSD) test at the $0.05 P$ level.

Measurements. Turf quality was visually rated on a scale of 1 to 9 , with a rating of 1 being a completely desiccated brown turf canopy, and a rating of 9 representing healthy plants with dark green, turgid leaf blades, and a dense turf canopy (Turgeon, 1999). A rating of 6 was considered the minimal acceptable turf quality level.

Vertical shoot growth rate was determined by measuring the difference in average canopy height between measurement dates using a ruler. The ruler was placed in three different areas of the canopy and brought to rest on the soil surface. Canopy height was measured as the average height of plants in each container.

Leaf photochemical efficiency was estimated by measuring the variable to maximum fluorescence ratio $\left(\mathrm{F}_{\mathrm{v}} / \mathrm{F}_{\mathrm{m}}\right)$ in the nonenergized state accomplished by exposure to darkness. Measurements were made of intact leaves with a chlorophyll fluorescence meter (ADC BioScientific, Hoddesdon, UK) after plants were adapted to darkness for $30 \mathrm{~min}$.

Water use characteristics were evaluated by measuring soil volumetric water content (VWC), leaf relative water content (RWC), evapotranspiration (ET), and $\psi_{\mathrm{S}}$ at full turgor $\left(\psi_{\pi 100}\right)$. Measurements were taken on a weekly basis. Soil volumetric water content in 0 to $20 \mathrm{~cm}$ soil depth (where most roots are located in turfgrass) was measured with the time domain reflectometry method (Soil Moisture Equipment, Santa Barbara, CA) using a 20-cm-long probe inserted in the soil. RWC was calculated using the formula: $100 \times[$ (fresh weight dry weight)/(turgid weight - dry weight)] after oven-drying leaf samples for $72 \mathrm{~h}$ at $100{ }^{\circ} \mathrm{C}$. Turgid weight was determined as fresh weight of fully turgid leaves after soaking leaves in distilled, refrigerated water for $24 \mathrm{~h}$. Leaves for RWC measurement were a random mix of old and new leaves and were cut from uniform and representative areas of the canopy. ET was determined by the gravimetric mass balance method. This was accomplished by weighing pots to calculate the total amount of water lost by comparing differences in pot weight between two measurement dates.

Osmotic potential $\left(\psi_{\pi 100}\right)$ was determined according to the rehydration method, where $\psi_{\pi 100}$ of leaves was determined after soaking in water for full rehydration (Blum, 1989; Blum and Sullivan, 1986). Turgid leaf samples were frozen in liquid nitrogen and were subsequently stored at $-20{ }^{\circ} \mathrm{C}$ until analysis of leaf $\psi_{\mathrm{s}}$. Frozen tissue samples were thawed and cell sap was pressed from leaves, which was subsequently analyzed for osmolality [C (millimoles per kilogram)] using a vapor pressure osmometer (Vapro model 5520; Wescor, Logan, UT). Osmolarity of cell sap was converted from millimoles per kilogram to $\psi_{\mathrm{S}}$ (megapascals) using the formula: $\mathrm{MPa}=-\mathrm{C} \times 2.58 \times 10^{-3}$. 


\section{Results}

SOIL AND PLANT WATER RELATIONS. The initial soil VWC under well-watered conditions averaged $27.4 \%$ in all treatments for both grass species (Table 1). During the 26-d period of drought, soil VWC of all treatments decreased to between $2.8 \%$ and $4.4 \%$. Kentucky bluegrass with TE treatment had significantly higher soil VWC than the untreated control at $13 \mathrm{~d}$ of drought, but no differences in VWC were observed between treatments at $26 \mathrm{~d}$ of drought stress. For creeping bentgrass, TE and ABA treatments maintained significantly higher soil VWC than the untreated control by 13 and $26 \mathrm{~d}$ of drought. Compared with ABA treatment, TE treatment had the same VWC at 0 and 26 $\mathrm{d}$ of drought, but higher VWC at $13 \mathrm{~d}$ of drought.

RWC of Kentucky bluegrass averaged $82 \%$ within $14 \mathrm{~d}$ of drought, and then declined rapidly after $14 \mathrm{~d}$ of drought in all treatments (Fig. 1A). The decline in RWC was more severe in untreated control plants than in TE- or ABA-treated plants. Significantly higher leaf RWC was observed in ABA-treated Kentucky bluegrass than in the untreated control at 20 and $27 \mathrm{~d}$ of drought stress. For creeping bentgrass, leaf RWC of untreated plants dropped sharply after $7 \mathrm{~d}$ of drought and was significantly lower than TE- or ABA-treated plants at 14 and $20 \mathrm{~d}$ of drought stress (Fig. 1B). No differences in RWC were observed between TE- and ABA-treated plants for Kentucky bluegrass or creeping bentgrass under well-watered conditions $(0 \mathrm{~d})$ or during drought stress.

ET rates of Kentucky bluegrass did not differ among treatments within $15 \mathrm{~d}$ of drought, but were significantly higher in TE-treated plants than the untreated control during 15 to $19 \mathrm{~d}$ of drought and were significantly higher in ABA-treated plants than the untreated control during 19 to $26 \mathrm{~d}$ of drought (Fig. 2A). TE- or ABA-treated creeping bentgrass had significantly lower rates of ET than the untreated control from 0 to $13 \mathrm{~d}$ of stress, but higher ET rates from 13 to $26 \mathrm{~d}$ of drought (Fig. 2B). No differences in ET rates were detected between TE and ABA treatments during the entire drought period.

Osmotic potential at full turgor $\left(\Psi \pi_{100}\right)$ was not impacted by $\mathrm{TE}$ or $\mathrm{ABA}$ treatment in Kentucky bluegrass before exposure to drought ( 0 d; Fig. 3A). However, $\Psi \pi_{100}$ in Kentucky bluegrass was significantly lower with $\mathrm{ABA}$ treatment at $21 \mathrm{~d}$ of drought and with TE and $\mathrm{ABA}$ treatments at $28 \mathrm{~d}$ of drought compared with the untreated control. For creeping bentgrass, $\Psi \pi_{100}$ was significantly lower with TE treatment at $21 \mathrm{~d}$ of drought and

Table 1. Soil volumetric water content in treatments with abscisic acid or trinexapac-ethyl during drought stress of 'Brilliant' Kentucky bluegrass and 'L-93' creeping bentgrass.

\begin{tabular}{|c|c|c|c|c|}
\hline \multirow[b]{3}{*}{ Species } & \multirow[b]{3}{*}{ Compound } & \multirow{2}{*}{\multicolumn{3}{|c|}{$\frac{\text { Soil volumetric content }(\%)}{\text { Days of treatment }}$}} \\
\hline & & & & \\
\hline & & 0 & 13 & 26 \\
\hline \multirow[t]{3}{*}{ Kentucky bluegrass } & Control & $26.1 \mathrm{a}^{\mathrm{z}}$ & $5.3 \mathrm{~b}$ & $3.8 \mathrm{a}$ \\
\hline & Abscisic acid & $28.0 \mathrm{a}$ & $6.1 \mathrm{~b}$ & $3.8 \mathrm{a}$ \\
\hline & Trinexapac-ethyl & $27.2 \mathrm{a}$ & $7.9 \mathrm{a}$ & $4.1 \mathrm{a}$ \\
\hline \multirow[t]{3}{*}{ Creeping bentgrass } & Control & $28.0 \mathrm{a}$ & $3.8 \mathrm{c}$ & $2.8 \mathrm{~b}$ \\
\hline & Abscisic acid & $27.4 \mathrm{a}$ & $6.4 \mathrm{~b}$ & $4.4 \mathrm{a}$ \\
\hline & Trinexapac-ethyl & $27.7 \mathrm{a}$ & $8.3 \mathrm{a}$ & $3.8 \mathrm{a}$ \\
\hline
\end{tabular}

\footnotetext{
${ }^{\mathrm{z}}$ Any two means within a column and plant species not followed by the same letter are significantly different by Duncan's multiple range test at $P \leq 0.05$.
}
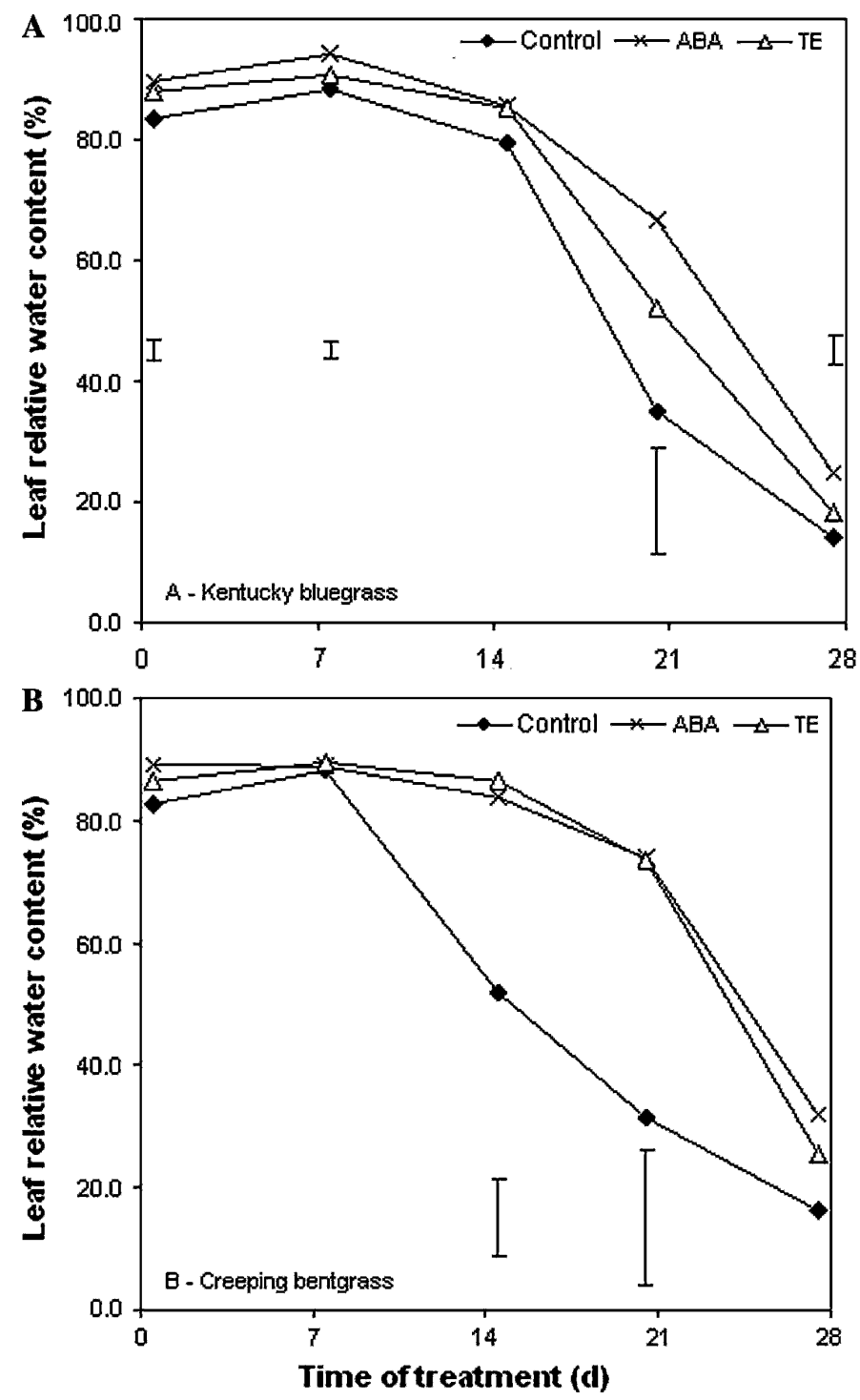

Fig. 1. Effects of foliar application of abscisic acid (ABA) or trinexapac-ethyl (TE) on leaf relative water content during drought stress for (A) 'Brilliant' Kentucky bluegrass and (B) 'L-93' creeping bentgrass. Vertical bars indicate LSD values $(P=0.05)$ for treatment comparisons at a given day of treatment.

with $\mathrm{TE}$ and $\mathrm{ABA}$ treatments at $28 \mathrm{~d}$ compared with the untreated control (Fig. 3B).

TURF GRowTH. Kentucky bluegrass treated with ABA or TE maintained turf quality at the same level as the untreated control under well-watered conditions ( $0 \mathrm{~d}$ of drought; Fig. 4A). However, TE-treated Kentucky bluegrass exhibited significantly higher turf quality than untreated turf at 7,21 , and $28 \mathrm{~d}$ of drought stress. ABA-treated Kentucky bluegrass had significantly higher turf quality than untreated turf at $28 \mathrm{~d}$ of drought stress. At 21 and $28 \mathrm{~d}$ of drought, Kentucky bluegrass treated with TE had higher turf quality than turf treated with ABA. For creeping bentgrass, TE-treated plants had lower turf quality than the untreated control at 0 and $7 \mathrm{~d}$ of drought, but maintained turf quality above the minimum acceptable level (6.0) and the untreated control level from 14 to $28 \mathrm{~d}$ of drought (Fig. 4B). No difference in turf quality was detected between $\mathrm{ABA}$ and untreated creeping bentgrass at 0 and $7 \mathrm{~d}$ of drought, but ABA-treated plants had significantly higher turf quality 

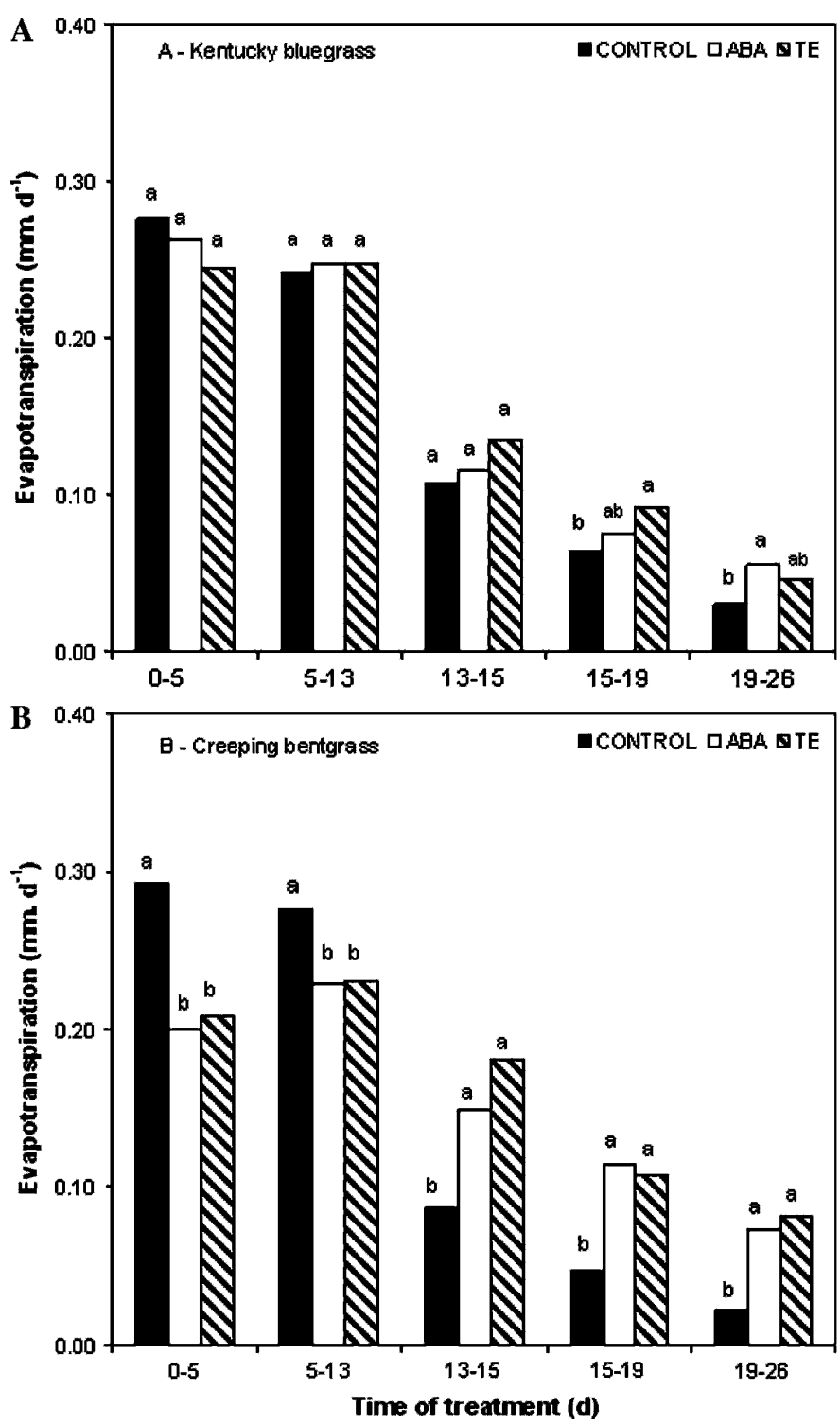

Fig. 2. Effects of foliar application of abscisic acid (ABA) or trinexapac-ethyl (TE) on evapotranspiration $\left(\mathrm{mm} \cdot \mathrm{d}^{-1}\right)$ during drought stress for (A) 'Brilliant' Kentucky bluegrass and (B) 'L-93' creeping bentgrass. Treatments with the same lowercase letters were not significantly different at a given day of treatment based on LSD values $(P=0.05)$.

than untreated control from 14 and $28 \mathrm{~d}$ of drought. ABAtreated creeping bentgrass had higher turf quality than TEtreated plants at 0 and $7 \mathrm{~d}$ of drought, but the difference diminished after $14 \mathrm{~d}$ of drought.

TE-treated plants had a significantly lower vertical shoot growth (VSG) rate than the respective untreated control for Kentucky bluegrass and creeping bentgrass during 1 to $4 \mathrm{~d}$ of drought treatment (Table 2). Creeping bentgrass treated with ABA also had lower VSG than the untreated control within the first $4 \mathrm{~d}$ of drought. During 4 to $15 \mathrm{~d}$ of drought, VSG of the untreated Kentucky bluegrass decreased by $87 \%$, whereas TEtreated plants maintained the same level of VSG as wellwatered plants, and the VSG of TE-treated plants was three times greater than that of the untreated control and $\mathrm{ABA}$-treated plants. For creeping bentgrass, a $91 \%$ reduction in VSG was detected in the untreated control plants from 4 to $15 \mathrm{~d}$ of drought compared with well-watered conditions, whereas TEor ABA-treated plants did not exhibit a significant decline in VSG when comparing well-watered conditions to 4 to $15 \mathrm{~d}$ of drought. In addition, the VSG for ABA- and TE-treated creeping bentgrass was two and three times greater, respectively, than the untreated control during 4 to $15 \mathrm{~d}$ of drought. TE treatment in Kentucky bluegrass regulated greater growth inhibition than ABA treatment under well-watered conditions, but maintained higher VSG than the ABA treatment during $15 \mathrm{~d}$ of drought. TE and ABA treatments had similar effects on VSG for creeping bentgrass under well-watered or drought conditions.

Рнотоснеmical efficiency. Untreated plants showed a more rapid decline in leaf photochemical efficiency than TE- or ABA-treated plants during $27 \mathrm{~d}$ of drought for both species (Fig. 5). Higher $\mathrm{F}_{\mathrm{v}} / \mathrm{F}_{\mathrm{m}}$ ratios were detected in ABA- and TE-treated Kentucky bluegrass at $21 \mathrm{~d}$ of drought and in ABAtreated bluegrass at $27 \mathrm{~d}$ of drought compared with the untreated control (Fig. 5A). TE- and ABA-treated creeping bentgrass exhibited higher $\mathrm{F}_{\mathrm{v}} / \mathrm{F}_{\mathrm{m}}$ than the untreated control at 15, 21, and $27 \mathrm{~d}$ of drought (Fig. 5B). TE treatment and ABA

$\mathbf{A}$

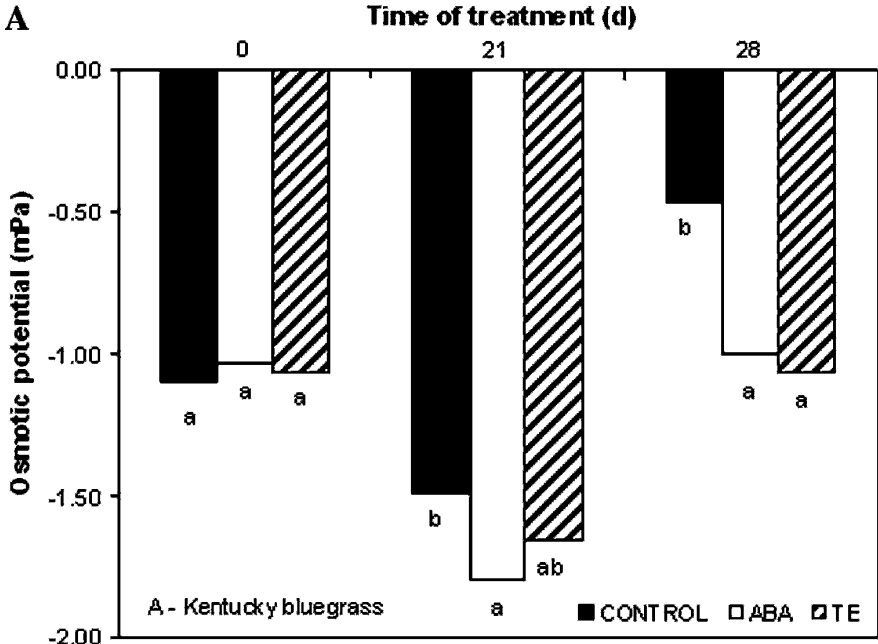

B Time of treatment (d)

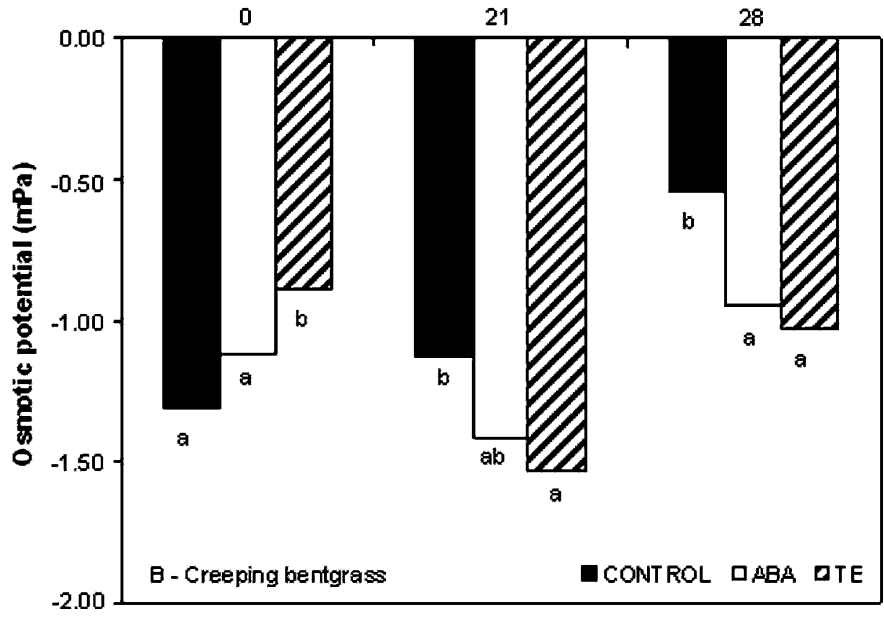

Fig. 3. Effects of foliar application of abscisic acid (ABA) or trinexapacethyl (TE) on $\psi_{\mathrm{S}}$ during drought stress for (A) 'Brilliant' Kentucky bluegrass and (B) 'L-93' creeping bentgrass. Columns with the same lowercase letters were not significantly different at a given day of treatment based on LSD values $(P=0.05)$. 

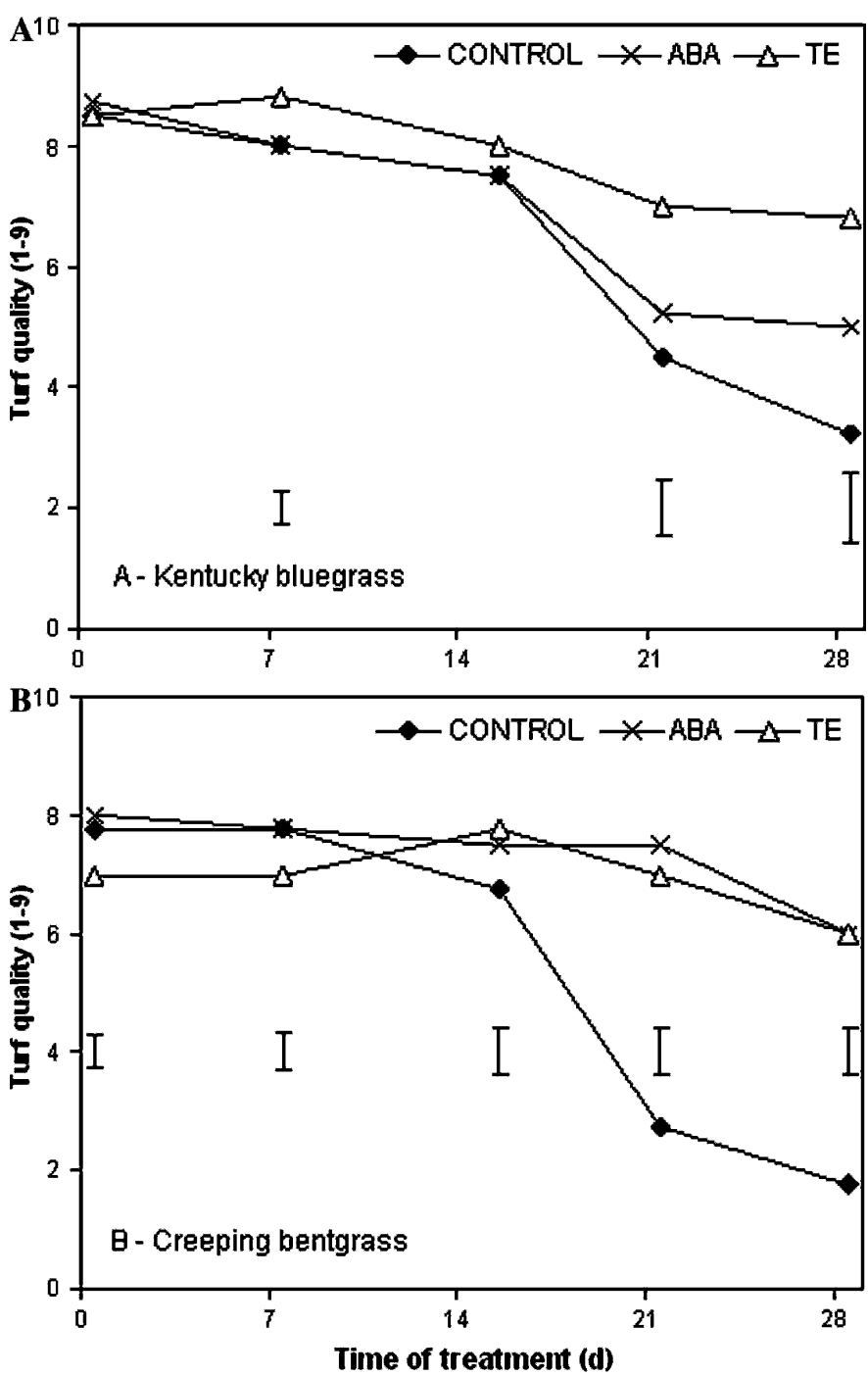

Fig. 4. Effects of foliar application of abscisic acid (ABA) or trinexapac-ethyl (TE) on turf quality during drought stress for (A) 'Brilliant' Kentucky bluegrass and (B) 'L-93' creeping bentgrass. Turf quality was expressed on a scale of 1 to $9(1=$ completely desiccated, brown turf canopy; $9=$ healthy plants with dark green, turgid leaf blades, and dense turf canopy). Vertical bars indicate LSD values $(P=0.05)$ for treatment comparisons at a given day of treatment. treatment had similar effects on $\mathrm{F}_{\mathrm{v}} / \mathrm{F}_{\mathrm{m}}$ ratio for both species during the entire drought period.

\section{Discussion}

TE or ABA application before turf exposure to drought stress helped maintain higher turf quality and shoot growth rate for Kentucky bluegrass and creeping bentgrass during prolonged periods of drought compared with the respective untreated controls. TE application at the manufacturer's recommended rate was more effective than ABA application in improving turf quality and maintaining active shoot growth rate for Kentucky bluegrass, but was equally effective as ABA treatment for creeping bentgrass. Maintenance of higher turf quality and active shoot growth of TE- or ABA-treated plants under long-term drought stress could be associated with the modification of morphological and physiological traits associated with drought avoidance and tolerance. These included slower shoot growth rate and reduced ET during the early phase of drought and improved plant water status and photochemical efficiency during prolonged drought in TE- or ABA-treated plants compared with untreated plants.

Foliar application of TE or ABA may promote drought avoidance in both species at the beginning of drought stress. The slower shoot growth rate during the early phase of drought may reduce demand for water, and thus sustain plant growth for a longer period of drought. In fact, creeping bentgrass treated with TE or ABA exhibited a significantly lower ET rate than the untreated control during the first $13 \mathrm{~d}$ of drought. Soil water content was also higher under TE-treated Kentucky bluegrass and TE-and ABA-treated creeping bentgrass at $13 \mathrm{~d}$ of drought, suggesting that $\mathrm{TE}$ or $\mathrm{ABA}$ treatment may result in lower water depletion rates due to growth inhibition during the early phase of drought. Previous studies evaluating Kentucky bluegrass and tall fescue have found lower rates of ET when TE was applied under nonstress conditions, possibly resulting from effects on growth inhibition (Ervin and Koski, 2001; Marcum and Jiang, 1997). ABA is also known to induce stomatal closure, leading to reduction in water loss (Finkelstein et al., 2002; Nambara and Marion-Poll, 2005). Stahnke and Beard (1981) reported that exogenous application of ABA reduced transpiration of creeping bentgrass by $59 \%$ compared with untreated plants under well-watered conditions. However, after a prolonged period of drought (19 d), ET rates in Kentucky bluegrass and creeping bentgrass treated with $\mathrm{TE}$ or $\mathrm{ABA}$ were significantly higher than the untreated control. This could be related to the maintenance of higher turf quality and normal shoot growth in TE- and ABA-treated plants at this time, and thus, a greater demand for water.

Improved water relations by $\mathrm{TE}$ or ABA treatment during prolonged periods of drought suggest that both treatments may also promote drought tolerance, which could contribute to the higher turf quality under prolonged periods of drought for Kentucky bluegrass and creeping bentgrass. Leaf RWC of the untreated control for Kentucky bluegrass and creeping bentgrass drop- 

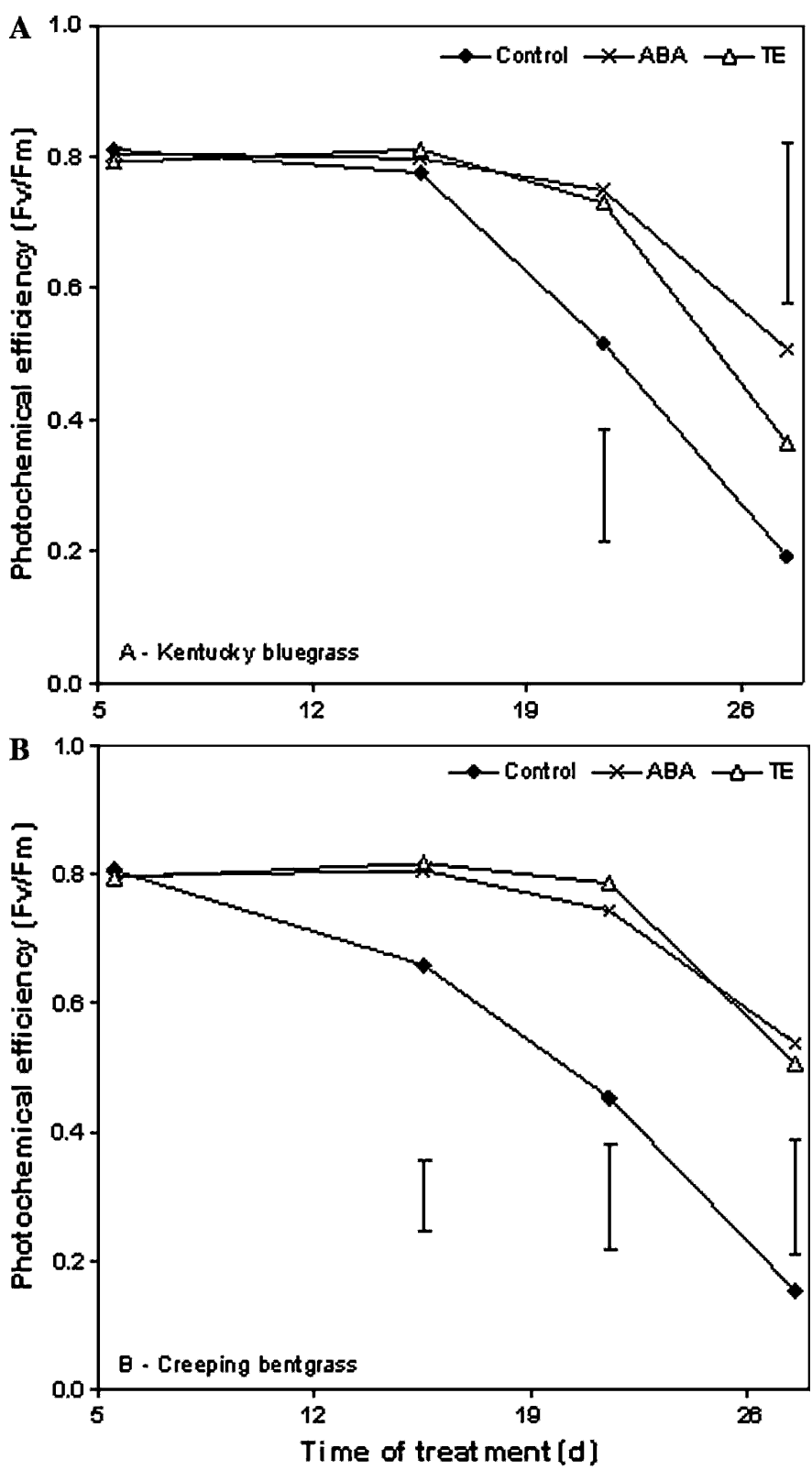

Fig. 5. Effects of foliar application of abscisic acid (ABA) or trinexapac-ethyl (TE) on photochemical efficiency $\left(\mathrm{F}_{\mathrm{v}} / \mathrm{F}_{\mathrm{m}}\right)$ during drought stress for (A) 'Brilliant' Kentucky bluegrass and (B) 'L-93' creeping bentgrass. Vertical bars indicate LSD values $(P=0.05)$ for treatment comparisons at a given day of treatment.

ped sharply during drought stress, whereas RWC of TE- and ABA-treated plants exhibited less severe decline and was significantly higher in ABA-treated Kentucky bluegrass and TE- or ABA-treated creeping bentgrass after $14 \mathrm{~d}$ of drought. High leaf RWC may be the result of water retention through osmotic adjustment (Nilsen and Orcutt, 1996). Osmotic adjustment facilitates the maintenance of water retention and cell turgor through accumulation of organic or inorganic solutes, thus protecting tissues from desiccation as water potentials decrease (Bohnert et al., 1995). In the current study, $\psi_{\mathrm{S}}$ at full turgor or full hydration of TE- or ABA-treated turf was significantly lower than the untreated control, suggesting that TE or ABA application may help maintain cell hydration by increasing the accumulation of osmotic solutes, as reflected by lower $\psi_{\mathrm{S}}$, and thus improved drought tolerance. Increases in cellular osmotic adjustment associated with ABA treatment have been attributed to ABA-induced accumulation of sucrose, reducing sugars, and proline under water stress conditions (LaRosa et al., 1987). How foliar application of TE may affect $\psi_{\mathrm{S}}$ of plant cells is not clear.

Maintaining active photosynthetic activities is a critical factor controlling plant growth under stressful conditions, serving to provide carbohydrates for growth and maintenance (Woolhouse, 1986). TE- or ABA-treated Kentucky bluegrass was able to maintain a significantly higher photochemical efficiency than the untreated plants during prolonged periods of drought stress. This finding is consistent with our previous results of improved photochemical efficiency with TE treatment for creeping bentgrass exposed to combined heat and drought (McCann and Huang, 2007) and with ABA treatment for Kentucky bluegrass exposed to drought stress (Wang et al., 2003). TE or ABA treatment helped maintain the integrity of photosystem II for photosynthesis. Rajasekaran and Blake (1999) reported that old jack pine seedlings treated with ABA maintained a higher photosynthetic rate, which was related to the protective action of ABA on membrane integrity during drought stress.

Although the results here are encouraging for the development of a field trial, the complex interactions of environmental factors can diminish or negate findings from controlled-environment experiments. Jiang and Fry (1998) have previously found that the improved drought tolerance of ryegrass treated with ethephon or TE in greenhouse trials did not result in improved drought tolerance under field conditions. Regardless, the data warrant further research to evaluate plant impact under field conditions.

In summary, our data suggested that foliar application of TE or ABA improved turf quality and growth for creeping bentgrass and Kentucky bluegrass exposed to drought stress. $\mathrm{TE}$ and $\mathrm{ABA}$ treatments promoted drought avoidance during the early phase of stress, as suggested by an initial reduction in shoot growth rate and ET rate, and improved drought tolerance during prolonged stress, as manifested by the maintenance of higher RWC, lower $\psi_{\mathrm{S}}$, and higher photochemical efficiency later in the process of drought stress. The combination of avoidance and tolerance mechanisms could result in an improvement in turf performance after TE or ABA application.

\section{Literature Cited}

Alves, A.A.C. and T.L. Setter. 2000. Response of cassava to water deficit: Leaf area growth and abscisic acid. Crop Sci. 40:131-137.

Bacon, M.A., S. Wilkinson, and W.J. Davies. 1998. pH-regulated leaf cell expansion in droughted plants is abscisic acid dependent. Plant Physiol. 118:1507-1515.

Blum, A. 1989. Osmotic adjustment and growth of barley genotypes under drought stress. Crop Sci. 29:230-233.

Blum, A. and C.Y. Sullivan. 1986. The comparative drought resistance of landraces of sorghum and millet from dry and humid regions. Annals of Botany. 57:835-846.

Bochicchio, A., C. Vazzana, R. Velasco, M. Singh, and D. Bartels. 1991. Exogenous ABA induces desiccation tolerance and leads to the synthesis of specific gene transcripts in immature embryos of maize. Maydica 36:11-16.

Bohnert, H.J., D.E. Nelson, and R.G. Jensen. 1995. Adaptations to environmental stresses. Plant Cell 7:1099-1111. 
Ervin, E.H. and A.J. Koski. 2001. Trinexapac-ethyl effects on kentucky bluegrass evapotranspiration. Crop Sci. 41(1):247-250.

Fagerness, M.J. and F.H. Yelverton. 2001. Plant growth regulator and mowing height effects on seasonal root growth of Penncross creeping bentgrass. Crop Sci. 41:1901-1905.

Finkelstein, R.R., S.S. Gampala, and C.D. Rock. 2002. The abscisic acid signaling in seeds and seedlings. Plant Cell 14:S15-S45.

Franks, P.J. and G.D. Farquhar. 2001. The effect of exogenous abscisic acid on stomatal development, stomatal mechanics, and leaf gas exchange in Tradescantia virginiana. Plant Physiol. 125:935942.

Huang, B. and Y. Jiang. 2002. Physiological and biochemical responses of plants to drought and heat stress, p. 287-301. In: M. Kang (ed.). Crop improvement: Challenges in the twenty-first century. Food Products Press, New York.

Jiang, H. and J. Fry. 1998. Drought responses of perennial ryegrass treated with plant growth regulators. HortScience 33:270-273.

Jiang, Y. and B. Huang. 2002. Protein alterations in tall fescue in response to drought stress and abscisic acid. Crop Sci. 42:202207.

Kang, M.S. (Editor). 2002. Crop improvement: Challenges in the twenty-first century. Haworth Press, Binghamton, NY.

King, R.W., G.F.W. Gocal, and O.M. Heide. 1997. Regulation of leaf growth and flowering of cool season turf grasses. Intl. Turf. Soc. Res. J. 8:565-573.

Kirkham, M.B. 1983. Effect of ABA on the water relations of winterwheat cultivars varying in drought resistance. Physiol. Plant. 59:153157.

Kondoh, S., H. Yahata, T. Nakashizuka, and M. Kondoh. 2006. Interspecific variation in vessel size, growth and drought tolerance of broad-leaved trees in semi-arid regions of Kenya. Tree Physiol. 26:899-904.

LaRosa, C.P., P.M. Hasegawa, D. Rhodes, J.M. Clithero, A.A. Watad, and R.A. Bressan. 1987. Abscisic acid stimulated osmotic adjustment and its involvement in adaptation of tobacco cells to $\mathrm{NaCl}$. Plant Physiol. 85:174-181.

Leskovar, D.I. and D.J. Cantliffe. 1992. Pepper seedling growth response to drought stress and exogenous abscisic acid. J. Amer. Soc. Hort. Sci. 117:389-393.
Marcum, K.B. and H. Jiang. 1997. Effects of plant growth regulators on tall fescue rooting and water use. J. Turfgrass Mgt. 2:13-27.

McCann, S.E. and B. Huang. 2007. Effects of trinexapac-ethyl in creeping bentgrass responses to combined drought and heat stress. Crop Sci. (in press).

Nambara, E. and A. Marion-Poll. 2005. Abscisic acid biosynthesis and catabolism. Annu. Rev. Plant Biol. 56:165-185.

Nilsen, E.T. and D.M. Orcutt. 1996. Physiology of plants under stress-Abiotic factors. Wiley, New York.

O'Reagan, B.P., W.A. Cress, and J. van Staden. 1993. Root growth, water relations, abscisic acid and proline levels of drought-resistant and drought-sensitive maize cultivars in response to water stress. S. Afr. J. Bot. 59:98-104.

Rajasekaran, L.R. and T.J. Blake. 1999. New plant growth regulators protect photosynthesis and enhance growth under drought of jack pine seedlings. J. Plant Growth Regulat. 18:175-181.

Simane, B., J.M. Peacock, and P.C. Struik. 1993. Differences in developmental plasticity and growth rate among drought-resistant and susceptible cultivars of durum wheat (Triticum turgidum L. var. durum). Plant Soil 157:155-166.

Stahnke, G.K. and J.B. Beard. 1981. Evaluation of antitranspirants on creeping bentgrass (Agrostis palustris Huds., cv. 'Penncross') and bermudagrass (Cynodon dactylon (L.) Pers. $\times$ Cynodon transvaalensis Burtt-Davy, cv. 'Tifway'). Agron. Abstr. p. 128.

Turgeon, A.J. 1999. Turfgrass management. 5th ed. Prentice Hall, Upper Saddle, NJ.

Wang, Z., B. Huang, and Q. Xu. 2003. Effects of abscisic acid on drought responses of kentucky bluegrass. J. Amer. Soc. Hort. Sci. 128:36-41

Wilkinson, S. and W.J. Davies. 2002. ABA-based chemical signaling: The coordination of responses to stress in plants. Plant Cell Environ. 25:195-210.

Woolhouse, H.W. 1986. Adaptation of photosynthesis to stress-A critical appraisal of current approaches and future perspectives. p. 112. In: N.R. Baker and S.P. Long (eds.). Photosynthesis in contrasting environments. John Innes Institute, Norwich, UK.

Zhang, X. and R.E. Schmidt. 2000. Application of trinexapac-ethyl and propiconazole enhances superoxide dismutase and photochemical activity in creeping bentgrass. J. Amer. Soc. Hort. Sci. 125:47-51. 